Research Article

\title{
Structural, Thermal, Optical, Electrical, and Adhesive Characteristics of FePdB Thin Films
}

\author{
Yuan-Tsung Chen \\ Graduate School of Materials Science, National Yunlin University of Science and Technology, 123 University Road, Section 3, \\ Douliou, Yunlin 64002, Taiwan
}

Correspondence should be addressed to Yuan-Tsung Chen; ytchen@yuntech.edu.tw

Received 6 February 2015; Revised 10 April 2015; Accepted 21 April 2015

Academic Editor: Mohamed Bououdina

Copyright (C) 2015 Yuan-Tsung Chen. This is an open access article distributed under the Creative Commons Attribution License, which permits unrestricted use, distribution, and reproduction in any medium, provided the original work is properly cited.

To study the structural, thermal, electrical, optical, and adhesive properties of magnetic FePdB thin films, 25-200- $\AA$-thick $\mathrm{Fe}_{40} \mathrm{Pd}_{40} \mathrm{~B}_{20}$ and $\mathrm{Fe}_{60} \mathrm{Pd}_{20} \mathrm{~B}_{20}$ films were deposited on a glass substrate by direct current (DC) magnetron sputtering at room temperature (RT). X-ray diffraction (XRD) patterns indicated that the 25-75- $\AA$-thick $\mathrm{Fe}_{40} \mathrm{Pd}_{40} \mathrm{~B}_{20}$ and $\mathrm{Fe}_{60} \mathrm{Pd}_{20} \mathrm{~B}_{20}$ films were amorphous, whereas the 100-200- $\AA$-thick $\mathrm{Fe}_{40} \mathrm{Pd}_{40} \mathrm{~B}_{20}$ and $\mathrm{Fe}_{60} \mathrm{Pd}_{20} \mathrm{~B}_{20}$ films were crystalline, with a face-centered cubic (FCC) FePd (111) textured structure. The activation energy of the $\mathrm{Fe}_{40} \mathrm{Pd}_{40} \mathrm{~B}_{20}$ and $\mathrm{Fe}_{60} \mathrm{Pd}_{20} \mathrm{~B}_{20}$ thin films decreased as thickness was increased. The 25 - $\AA$-thick $\mathrm{Fe}_{40} \mathrm{Pd}_{40} \mathrm{~B}_{20}$ film exhibited the highest resistivity, whereas the 200 - $\AA$-thick $\mathrm{Fe}_{60} \mathrm{Pd}_{20} \mathrm{~B}_{20}$ film exhibited the lowest resistivity. Increasing the thickness and crystallization reduced transmission. The $\mathrm{Fe}_{40} \mathrm{Pd}_{40} \mathrm{~B}_{20}$ thin films exhibited higher surface energy and stronger adhesion than did $\mathrm{Fe}_{60} \mathrm{Pd}_{20} \mathrm{~B}_{20}$ thin films.

\section{Introduction}

FePdB is a new ferromagnetic (FM) material, which can be inserted to magnetic tunnel junction (MTJ) with a free layer or pinned layer in high-density read/write head sensors, spin-valve structures, and magnetoresistance random access memory (MRAM) applications [1-3]. To obtain both high recording density and high tunneling magnetoresistance (TMR), various perpendicular magnetic anisotropy (PMA) materials are used in combination with FM materials such as FePdB, which are known to provide high TMR and $\mathrm{MgO}$ tunnel barriers $[4,5]$. FePdB alloy metal, a newly developed material, has a huge range of unknown uncertainty that attracted great attention to its characteristics. Transparent $\mathrm{ZnO}$ film was also used with FePdB magnetic film to form a bilayer, which can be used in magnetic and photoelectrical applications [6]. It would be of interest to study the relationship between crystalline structural, thermal, optical, electric, and adhesive effects of magnetic FePdB thin films. FePdB alloy is a soft FM material of which investigations are scarce. The research group of Choi et al. reported that FePdB film was placed to $\mathrm{CoFeB}$ film as the top and bottom FM layers of MTJs, thus indicating the substantial interest in examining FePdB film [5]. This study investigated the characteristics of crystalline structural, thermal, electric, optical, and adhesive effects of magnetic FePdB thin films.

\section{Experimental Details}

FePdB thin films $(25,50,75,100$, and $200 \AA)$ were deposited on a glass substrate at room temperature (RT) through direct current (DC) magnetron sputtering. The typical base chamber pressure exceeded $2 \times 10^{-6}$ Torr, and the Ar working chamber pressure was $5 \times 10^{-3}$ Torr. The target compositions of the two FePdB alloys were 40 at.\% Fe, 40 at.\% Pd, and 20 at.\% B and 60 at.\% Fe, 20 at.\% Pd, and 20 at.\% B. Xray diffraction (XRD) with a $\mathrm{CuK}_{\alpha 1}$ line (Philips X'pert) was adopted to determine the structures of the alloys. The thermal properties of the FePdB thin films were determined using differential scanning calorimetry (DSC) at heating rates of $10-40 \mathrm{~K} / \mathrm{min}$. The electrical properties of the FePdB thin films at RT were studied using a traditional four-point resistance meter. The optical properties of the FePdB thin films were determined using Spectra Smart Analyzer. The surface energy of the FePdB films was calculated based on measurements of the contact angle, using water and diiodomethane as test liquids. 


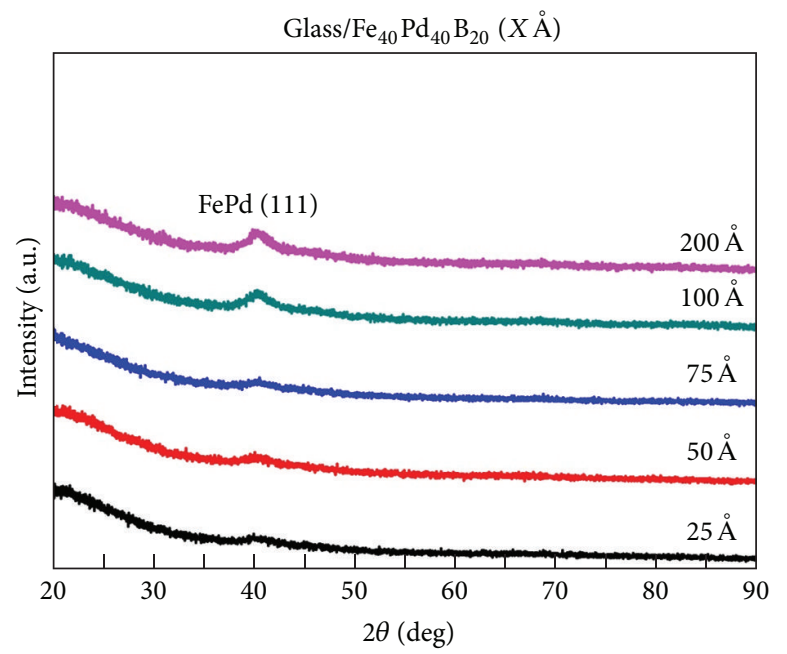

(a)

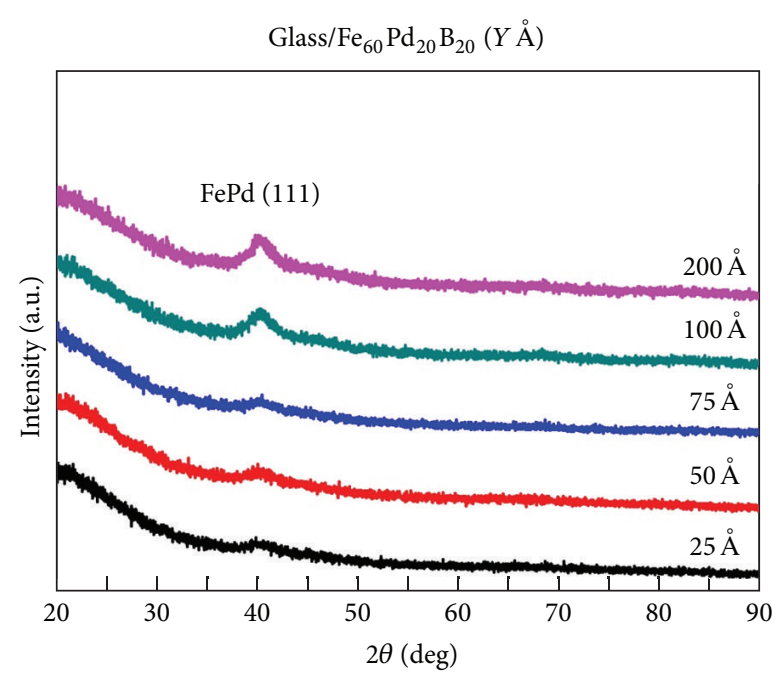

(b)

FIgURE 1: X-ray diffraction patterns of FePdB thin films. (a) $\mathrm{Fe}_{40} \mathrm{Pd}_{40} \mathrm{~B}_{20}$ and (b) $\mathrm{Fe}_{60} \mathrm{Pd}_{20} \mathrm{~B}_{20}$.

\section{Results and Discussion}

3.1. Structure and Thermal Properties. Figures $1(\mathrm{a})$ and $1(\mathrm{~b})$ show the XRD patterns of the $\mathrm{Fe}_{40} \mathrm{Pd}_{40} \mathrm{~B}_{20}$ and $\mathrm{Fe}_{60} \mathrm{Pd}_{20} \mathrm{~B}_{20}$ thin films in $2 \theta$ range from $20^{\circ}$ to $90^{\circ}$ [7]. The XRD results revealed that the thinnest $25 \AA$-thick $\mathrm{Fe}_{40} \mathrm{Pd}_{40} \mathrm{~B}_{20}$ and $\mathrm{Fe}_{60} \mathrm{Pd}_{20} \mathrm{~B}_{20}$ films were similar to XRD pattern of glass substrate. The thinnest $25 \AA$-thick $\mathrm{Fe}_{40} \mathrm{Pd}_{40} \mathrm{~B}_{20}$ and $\mathrm{Fe}_{60} \mathrm{Pd}_{20} \mathrm{~B}_{20}$ films were of amorphous structure. Moreover, the thicker 50-75- $\AA$-thick $\mathrm{Fe}_{40} \mathrm{Pd}_{40} \mathrm{~B}_{20}$ and $\mathrm{Fe}_{60} \mathrm{Pd}_{20} \mathrm{~B}_{20}$ films were no apparent crystalline phenomena and the structures were also of amorphous status. An obvious face-centered cubic (FCC) structure and an FePd (111) crystalline peak with an approximately $2 \theta$ of $40^{\circ}$ were identified in 100-200- $\AA$-thick $\mathrm{Fe}_{40} \mathrm{Pd}_{40} \mathrm{~B}_{20}$ and $\mathrm{Fe}_{60} \mathrm{Pd}_{20} \mathrm{~B}_{20}$ films. According to previous references $[8,9]$, it can also reasonably be concluded that the diffracted peak is FePd (111). Therefore, the FCC FePd (111) was identified herein. The main crystalline peak of the $\mathrm{Fe}_{60} \mathrm{Pd}_{20} \mathrm{~B}_{20}$ thin film was stronger than that of the $\mathrm{Fe}_{40} \mathrm{Pd}_{40} \mathrm{~B}_{20}$ thin film. This result indicated that the crystallization of the $\mathrm{Fe}_{60} \mathrm{Pd}_{20} \mathrm{~B}_{20}$ thin film was more favorable than that of the $\mathrm{Fe}_{40} \mathrm{Pd}_{40} \mathrm{~B}_{20}$ thin film. Thermal analysis was performed to clarify this result.

Figure 2 shows the activation energy $(Q)$ of crystallization of the 25-75- $\AA$-thick $\mathrm{Fe}_{40} \mathrm{Pd}_{40} \mathrm{~B}_{20}$ and $\mathrm{Fe}_{60} \mathrm{Pd}_{20} \mathrm{~B}_{20}$ films [7]. The activation energy was determined using Kissinger fitting as a function of thickness. Because these films were amorphous according to $\mathrm{XRD}$, the activation energy $(Q$ value) of the $25-75$ - $\AA$-thick $\mathrm{Fe}_{40} \mathrm{Pd}_{40} \mathrm{~B}_{20}$ film decreased from 86.3 to $66.1 \mathrm{~kJ} / \mathrm{mole}$, and the $Q$ value of the $25-75-\AA$-thick $\mathrm{Fe}_{60} \mathrm{Pd}_{20} \mathrm{~B}_{20}$ film decreased from 49.8 to $44.1 \mathrm{~kJ} / \mathrm{mole}$. The activation energy of both the $\mathrm{Fe}_{40} \mathrm{Pd}_{40} \mathrm{~B}_{20}$ and $\mathrm{Fe}_{60} \mathrm{Pd}_{20} \mathrm{~B}_{20}$ thin films decreased as the thickness increased, thus lowering the $Q$ value and promoting crystallization. Higher activation energy corresponds to stronger resistance to crystallization. The 75- $\AA$-thick FePdB film exhibited the lowest activation energy. The amorphous state can be easily transformed into

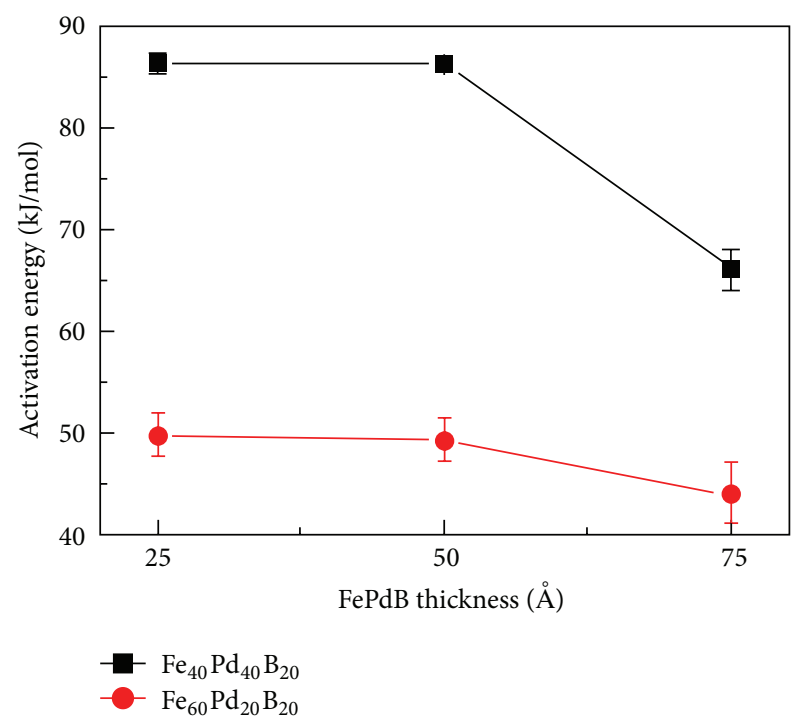

FIGURE 2: Activation energy estimated from Kissinger-fitted plots for amorphous $\mathrm{Fe}_{40} \mathrm{Pd}_{40} \mathrm{~B}_{20}$ and $\mathrm{Fe}_{60} \mathrm{Pd}_{20} \mathrm{~B}_{20}$ thin film with thicknesses of $25-75 \AA$.

a crystalline structure by applying a thermal driving force. In contrast to the 25-75- $\AA$-thick $\mathrm{Fe}_{40} \mathrm{Pd}_{40} \mathrm{~B}_{20}$ and $\mathrm{Fe}_{60} \mathrm{Pd}_{20} \mathrm{~B}_{20}$ films, both 25- $\AA$-thick $\mathrm{Fe}_{40} \mathrm{Pd}_{40} \mathrm{~B}_{20}$ and $\mathrm{Fe}_{60} \mathrm{Pd}_{20} \mathrm{~B}_{20}$ films exhibited the highest $Q$ value, suggesting that they were difficult to crystallize.

3.2. Electrical Analysis. Figures 3(a) and 3(b) show the electrical resistivity $(\rho)$ of the $\mathrm{Fe}_{40} \mathrm{Pd}_{40} \mathrm{~B}_{20}$ and $\mathrm{Fe}_{60} \mathrm{Pd}_{20} \mathrm{~B}_{20}$ thin films with five thicknesses. The electrical resistivity decreased as the thickness of the $\mathrm{Fe}_{40} \mathrm{Pd}_{40} \mathrm{~B}_{20}$ and $\mathrm{Fe}_{60} \mathrm{Pd}_{20} \mathrm{~B}_{20}$ films increased. The resistivity value of the $\mathrm{Fe}_{40} \mathrm{Pd}_{40} \mathrm{~B}_{20}$ films decreased from 23176 to $6828 \Omega \cdot \mathrm{cm}$, and the resistivity value of the $\mathrm{Fe}_{60} \mathrm{Pd}_{20} \mathrm{~B}_{20}$ films decreased from 4710 to $1145 \Omega \cdot \mathrm{cm}$. 


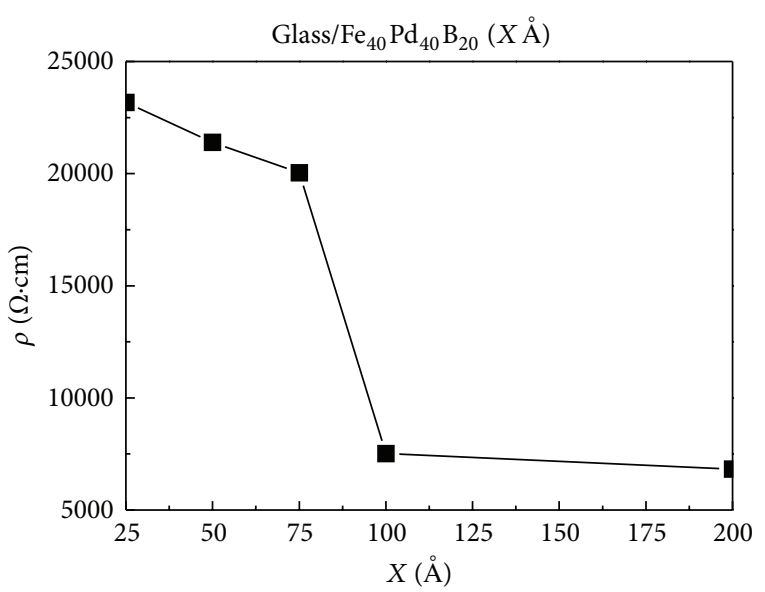

(a)

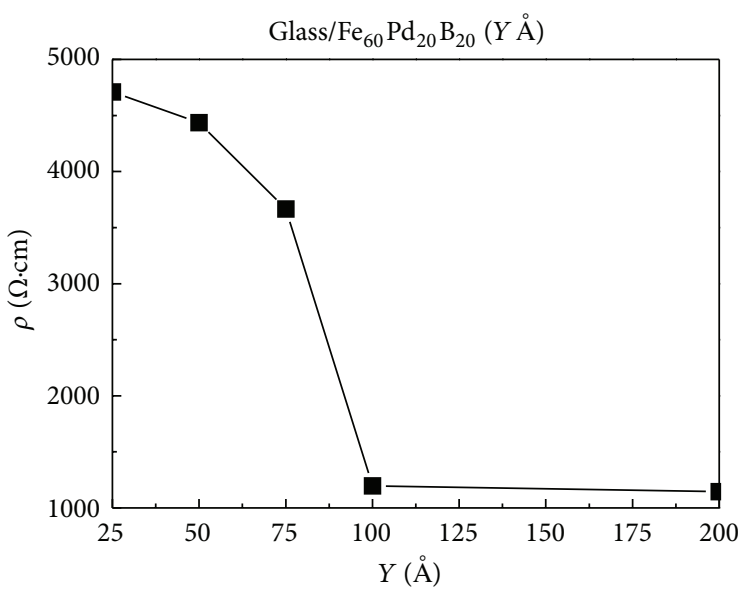

(b)

Figure 3: Electrical resistivity $(\rho)$ as a function of $\mathrm{Fe}_{40} \mathrm{Pd}_{40} \mathrm{~B}_{20}$ and $\mathrm{Fe}_{60} \mathrm{Pd}_{20} \mathrm{~B}_{20}$ thickness. (a) $\mathrm{Fe}_{40} \mathrm{Pd}_{40} \mathrm{~B}_{20}$ and (b) $\mathrm{Fe}_{60} \mathrm{Pd}_{20} \mathrm{~B}_{20}$.

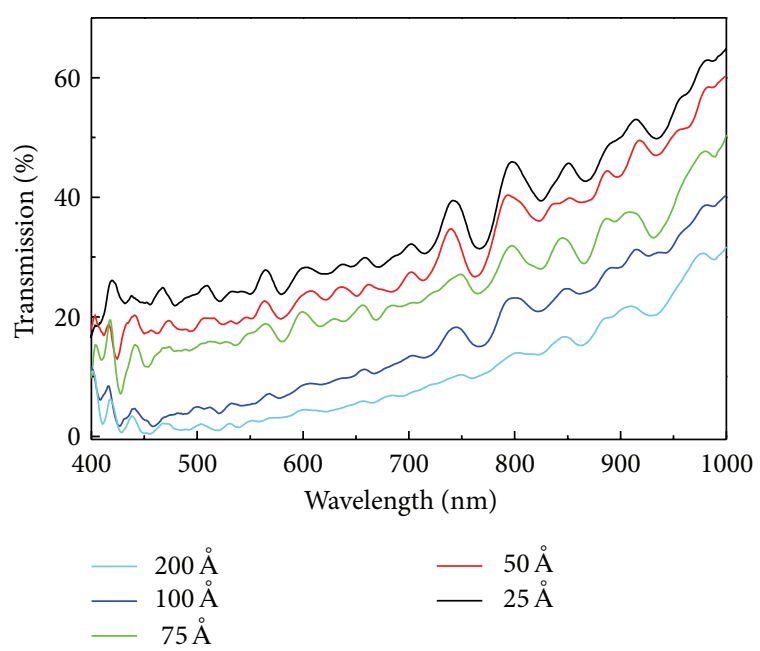

(a)

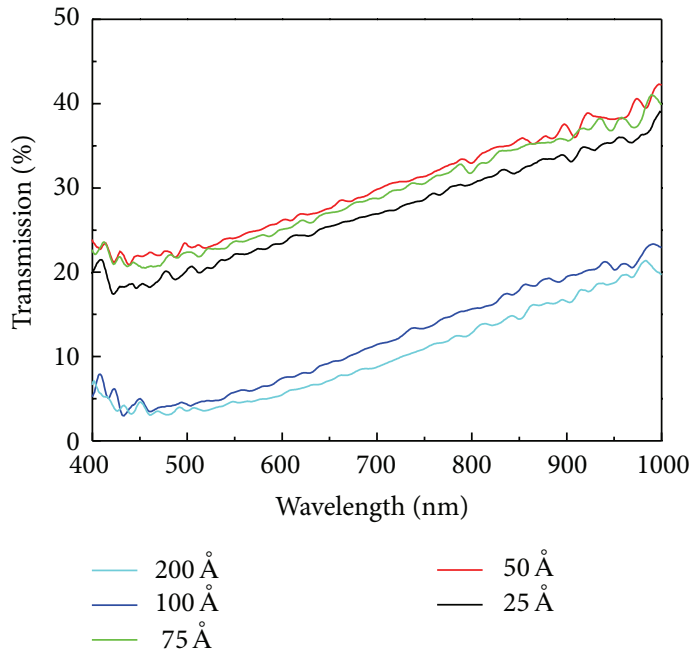

(b)

Figure 4: The transmission (\%) of optical property as a function of $\mathrm{Fe}_{40} \mathrm{Pd}_{40} \mathrm{~B}_{20}$ and $\mathrm{Fe}_{60} \mathrm{Pd}_{20} \mathrm{~B}_{20}$ thin film thickness. (a) $\mathrm{Fe}_{40} \mathrm{Pd}_{40} \mathrm{~B}_{20}$ and (b) $\mathrm{Fe}_{60} \mathrm{Pd}_{20} \mathrm{~B}_{20}$.

Thus, the 25- $\AA$-thick $\mathrm{Fe}_{40} \mathrm{Pd}_{40} \mathrm{~B}_{20}$ film exhibited the highest resistivity, whereas the 200 - $\AA$-thick $\mathrm{Fe}_{60} \mathrm{Pd}_{20} \mathrm{~B}_{20}$ film exhibited the lowest resistivity. The scattering of electrons from the grain boundaries and surface, as well as greater crystallization, causes thicker films to have higher resistivity $[10,11]$. According to the XRD results, the crystallization of the $\mathrm{Fe}_{60} \mathrm{Pd}_{20} \mathrm{~B}_{20}$ thin films was more favorable than that of the $\mathrm{Fe}_{40} \mathrm{Pd}_{40} \mathrm{~B}_{20}$ thin films. The resistivity value of the $\mathrm{Fe}_{40} \mathrm{Pd}_{40} \mathrm{~B}_{20}$ films of any thickness was higher than that of $\mathrm{Fe}_{60} \mathrm{Pd}_{20} \mathrm{~B}_{20}$ films. Comparison to other magnetic $\mathrm{Fe}_{2} \mathrm{Si}$ thin films reveals that the resistivity value of FePdB films is around 9 times smaller than $\mathrm{Fe}_{2} \mathrm{Si}$ films [12]. Magnetic FePdB films are typically applied in semiconductor processes, and resistivity is a critical parameter in electrical applications.

3.3. Optical Analysis. Figures 4(a) and 4(b) show the optical transmission $(T \%)$ of the $\mathrm{Fe}_{40} \mathrm{Pd}_{40} \mathrm{~B}_{20}$ and $\mathrm{Fe}_{60} \mathrm{Pd}_{20} \mathrm{~B}_{20}$ thin films with five thicknesses. When the wavelength was $1000 \mathrm{~nm}$ for the entire transmittance plot, this indicates that it was the highest transmittance value in the visible light wavelength $1000 \mathrm{~nm}$. As shown in Figure 4(a), when the total wavelength ranged from 400 to $1000 \mathrm{~nm}$, the transmission of the $\mathrm{Fe}_{40} \mathrm{Pd}_{40} \mathrm{~B}_{20}$ thin films gradually increased from approximately $20 \%$ to $63 \%$. As the thickness of the $\mathrm{Fe}_{40} \mathrm{Pd}_{40} \mathrm{~B}_{20}$ thin films increased, $T \%$ decreased. As shown in Figure 4(b), when the total wavelength ranged from 400 to $1000 \mathrm{~nm}$, the transmission of the $\mathrm{Fe}_{60} \mathrm{Pd}_{20} \mathrm{~B}_{20}$ thin film exhibited two gradually rising curves. The $T \%$ of the 25-75$\AA$-thick $\mathrm{Fe}_{60} \mathrm{Pd}_{20} \mathrm{~B}_{20}$ films increased from $20 \%$ to $40 \%$, but the $T \%$ of the $100-200-\AA$-thick $\mathrm{Fe}_{60} \mathrm{Pd}_{20} \mathrm{~B}_{20}$ films increased from $5 \%$ to $20 \%$. This phenomenon was inferred based on the crystallization observed using XRD. Large grains either in thicker films are reasonably concluded to inhibit the transfer of the photon signal through the film, causing low transmission [13]. 


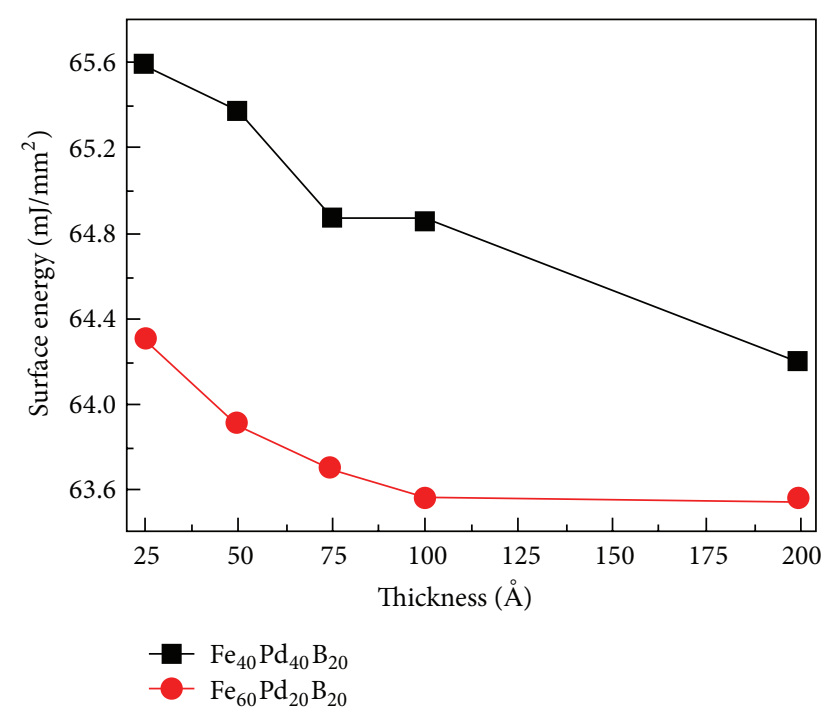

Figure 5: Surface energy as a function of $\mathrm{Fe}_{40} \mathrm{Pd}_{40} \mathrm{~B}_{20}$ and $\mathrm{Fe}_{60} \mathrm{Pd}_{20} \mathrm{~B}_{20}$ thickness.

3.4. Analysis of Surface Energy and Adhesion. The surface energy was determined based on the contact angle and some calculations [14-16]. Figure 5 shows the surface energy of the $\mathrm{Fe}_{40} \mathrm{Pd}_{40} \mathrm{~B}_{20}$ and $\mathrm{Fe}_{60} \mathrm{Pd}_{20} \mathrm{~B}_{20}$ thin films with five thicknesses. The surface energy of the $\mathrm{Fe}_{40} \mathrm{Pd}_{40} \mathrm{~B}_{20}$ thin films decreased (65.592 to $64.204 \mathrm{~mJ} / \mathrm{mm}^{2}$, black line of Figure 5) as the thickness was increased. The surface energy of $\mathrm{Fe}_{60} \mathrm{Pd}_{20} \mathrm{~B}_{20}$ thin films also decreased $\left(64.304\right.$ to $63.554 \mathrm{~mJ} / \mathrm{mm}^{2}$, red line of Figure 5) as the thickness was increased. The surface energy of the $\mathrm{Fe}_{40} \mathrm{Pd}_{40} \mathrm{~B}_{20}$ thin films was higher than that of the $\mathrm{Fe}_{60} \mathrm{Pd}_{20} \mathrm{~B}_{20}$ thin films. Low surface energy corresponds to weak adhesion. Thus, the adhesion capability of the $\mathrm{Fe}_{40} \mathrm{Pd}_{40} \mathrm{~B}_{20}$ thin films was higher than that of the $\mathrm{Fe}_{60} \mathrm{Pd}_{20} \mathrm{~B}_{20}$ thin films. Nevertheless, a high degree of crystallization results in low surface energy and weak adhesion [17]. According to the XRD results, the crystallization of the $\mathrm{Fe}_{60} \mathrm{Pd}_{20} \mathrm{~B}_{20}$ thin films was more favorable than that of the $\mathrm{Fe}_{40} \mathrm{Pd}_{40} \mathrm{~B}_{20}$ thin films. This analysis of surface energy and adhesion was consistent with the crystallization results obtained using XRD. Hence, the 25- $\AA$-thick $\mathrm{Fe}_{40} \mathrm{Pd}_{40} \mathrm{~B}_{20}$ film exhibited the lowest crystallization, as well as the highest surface energy and strongest adhesion, and can be used in adhesive applications such as free layers for magnetic tunnel junctions. In summary, the $\mathrm{Fe}_{60} \mathrm{Pd}_{20} \mathrm{~B}_{20}$ thin films exhibited more favorable crystallization, lower resistance, lower transmission, lower surface energy, and weaker adhesion than did the $\mathrm{Fe}_{40} \mathrm{Pd}_{40} \mathrm{~B}_{20}$ films.

\section{Conclusions}

The XRD patterns indicated that the 25-75- $\AA$-thick $\mathrm{Fe}_{40} \mathrm{Pd}_{40} \mathrm{~B}_{20}$ and $\mathrm{Fe}_{60} \mathrm{Pd}_{20} \mathrm{~B}_{20}$ films were amorphous, whereas the 100-200- $\AA$-thick $\mathrm{Fe}_{40} \mathrm{Pd}_{40} \mathrm{~B}_{20}$ and $\mathrm{Fe}_{60} \mathrm{Pd}_{20} \mathrm{~B}_{20}$ films were crystalline, with an FCC FePd (111) textured structure at approximately $2 \theta=40^{\circ}$. Because of their amorphous structure, the 25-75- $\AA$-thick $\mathrm{Fe}_{40} \mathrm{Pd}_{40} \mathrm{~B}_{20}$ and
$\mathrm{Fe}_{60} \mathrm{Pd}_{20} \mathrm{~B}_{20}$ films exhibited decreasing activation energy as the thickness was increased. The $75-\AA$-thick FePdB film exhibited the lowest activation energy. The 25- $\AA$-thick $\mathrm{Fe}_{40} \mathrm{Pd}_{40} \mathrm{~B}_{20}$ and $\mathrm{Fe}_{60} \mathrm{Pd}_{20} \mathrm{~B}_{20}$ films exhibited the highest $\mathrm{Q}$ value, suggesting that they are difficult to crystallize. The 25- $\AA$-thick $\mathrm{Fe}_{40} \mathrm{Pd}_{40} \mathrm{~B}_{20}$ film exhibited the highest resistivity, whereas the 200 - $\AA$-thick $\mathrm{Fe}_{60} \mathrm{Pd}_{20} \mathrm{~B}_{20}$ film exhibited the lowest resistivity. Transmission decreased when both thickness and crystallization increased. The $\mathrm{Fe}_{40} \mathrm{Pd}_{40} \mathrm{~B}_{20}$ thin films exhibited higher surface energy and stronger adhesion than did the $\mathrm{Fe}_{60} \mathrm{Pd}_{20} \mathrm{~B}_{20}$ thin films. The $\mathrm{Fe}_{40} \mathrm{Pd}_{40} \mathrm{~B}_{20}$ thin films exhibited less favorable crystallization, higher resistance, higher transmission, higher surface energy, and stronger adhesion than did the $\mathrm{Fe}_{60} \mathrm{Pd}_{20} \mathrm{~B}_{20}$ thin films.

\section{Conflict of Interests}

The author declares that there is no conflict of interests regarding the publication of this paper.

\section{Acknowledgment}

This work was supported by the Ministry of Science and Technology, under Grant no. MOST104-2112-M-224-002.

\section{References}

[1] Y.-T. Chen and J.-W. Ou, "Magnetic, optical, and electrical properties of $\mathrm{Fe}_{40} \mathrm{Pd}_{40} \mathrm{~B}_{20}$ thin-films," Journal of Alloys and Compounds, vol. 605, pp. 179-182, 2014.

[2] D. S. Li, H. Garmestani, S.-S. Yan et al., "Effects of high magnetic field annealing on texture and magnetic properties of FePd," Journal of Magnetism and Magnetic Materials, vol. 281, no. 2-3, pp. 272-275, 2004.

[3] J. Ko, T. Bae, and J. Hong, "Effect of a change in thickness on the structural and perpendicular magnetic properties of L10 ordered FePd ultra-thin films with (001) texture," Journal of Applied Physics, vol. 112, no. 11, Article ID 113919, 4 pages, 2012.

[4] C. Clavero, J. M. García-Martín, J. L. C. Krämer et al., “Temperature and thickness dependence at the onset of perpendicular magnetic anisotropy in FePd thin films sputtered on $\mathrm{MgO}(001)$," Physical Review B, vol. 73, no. 17, Article ID 174405, 2006.

[5] G. M. Choi, B. C. Min, and K. H. Shin, "FePdB layer for perpendicular magnetic tunnel junctions," Applied Physics Letters, vol. 97, no. 20, Article ID 202503, 2010.

[6] Y. T. Chen, H. Y. Jheng, and Y. B. Huang, "Low-frequency magnetic susceptibility and photoelectric properties of glass $/ \mathrm{Fe}_{40} \mathrm{Pd}_{40} \mathrm{~B}_{20} / \mathrm{ZnO}$ and glass $/ \mathrm{ZnO} / \mathrm{Fe}_{40} \mathrm{Pd}_{40} \mathrm{~B}_{20}$, Journal of Alloys and Compounds, vol. 599, pp. 223-227, 2014.

[7] Y. T. Chen, "The thermal properties of amorphous $\mathrm{Fe}_{40} \mathrm{Pd}_{40} \mathrm{~B}_{20}$ and $\mathrm{Fe}_{60} \mathrm{Pd}_{20} \mathrm{~B}_{20}$ thin films," Journal of Magnetism and Magnetic Materials, vol. 386, no. 2-3, pp. 141-145, 2015.

[8] B. Li, W. Liu, X. G. Zhao et al., "Ordering temperature of $\mathrm{L1}_{0}$ FePd film reduced by Ag underlayer," Materials Letters, vol. 100, pp. 58-61, 2013.

[9] A. Polit, D. Makarov, C. Brombacher et al., "Structural and magnetic properties of $\mathrm{Cu}$-alloyed FePd films," Journal of Magnetism and Magnetic Materials, vol. 381, pp. 316-321, 2015.

[10] N. Redjdal, H. Salah, T. Hauet et al., "Microstructural, electrical and magnetic properties of $\mathrm{Fe}_{35} \mathrm{Co}_{65}$ thin films grown by 
thermal evaporation from mechanically alloyed powders," Thin Solid Films, vol. 552, pp. 164-169, 2014.

[11] S. A. J. Jassim, A. A. R. A. Zumaila, and G. A. A. Al Waly, "Influence of substrate temperature on the structural, optical and electrical properties of CdS thin films deposited by thermal evaporation," Results in Physics, vol. 3, pp. 173-178, 2013.

[12] Y. T. Chen and Y. C. Tan, "The optical, magnetic, and electrical characteristics of $\mathrm{Fe}_{2} \mathrm{Si}$ thin films," Journal of Alloys and Compounds, vol. 615, pp. 946-949, 2014.

[13] R. Romero, F. Martin, J. R. Ramos-Barrado, and D. Leinen, "Synthesis and characterization of nanostructured nickel oxide thin films prepared with chemical spray pyrolysis," Thin Solid Films, vol. 518, no. 16, pp. 4499-4502, 2010.

[14] K. Ma, T. S. Chung, and R. J. Good, "Surface energy of thermotropic liquid crystalline polyesters and polyesteramide," Journal of Polymer Science, Part B: Polymer Physics, vol. 36, no. 13, pp. 2327-2337, 1998.

[15] D. K. Owens and R. C. Wendt, "Estimation of the surface free energy of polymers," Journal of Applied Polymer Science, vol. 13, no. 8, pp. 1741-1747, 1969.

[16] "A reinterpretation of organic liquid-polytetrafluoroethylene surface interactions," Journal of Adhesion, vol. 2, pp. 50-60, 1970.

[17] D. A. Porter and K. E. Easterling, Phase Transformations in Metals and Alloy, CRC, 2nd edition, 1992. 

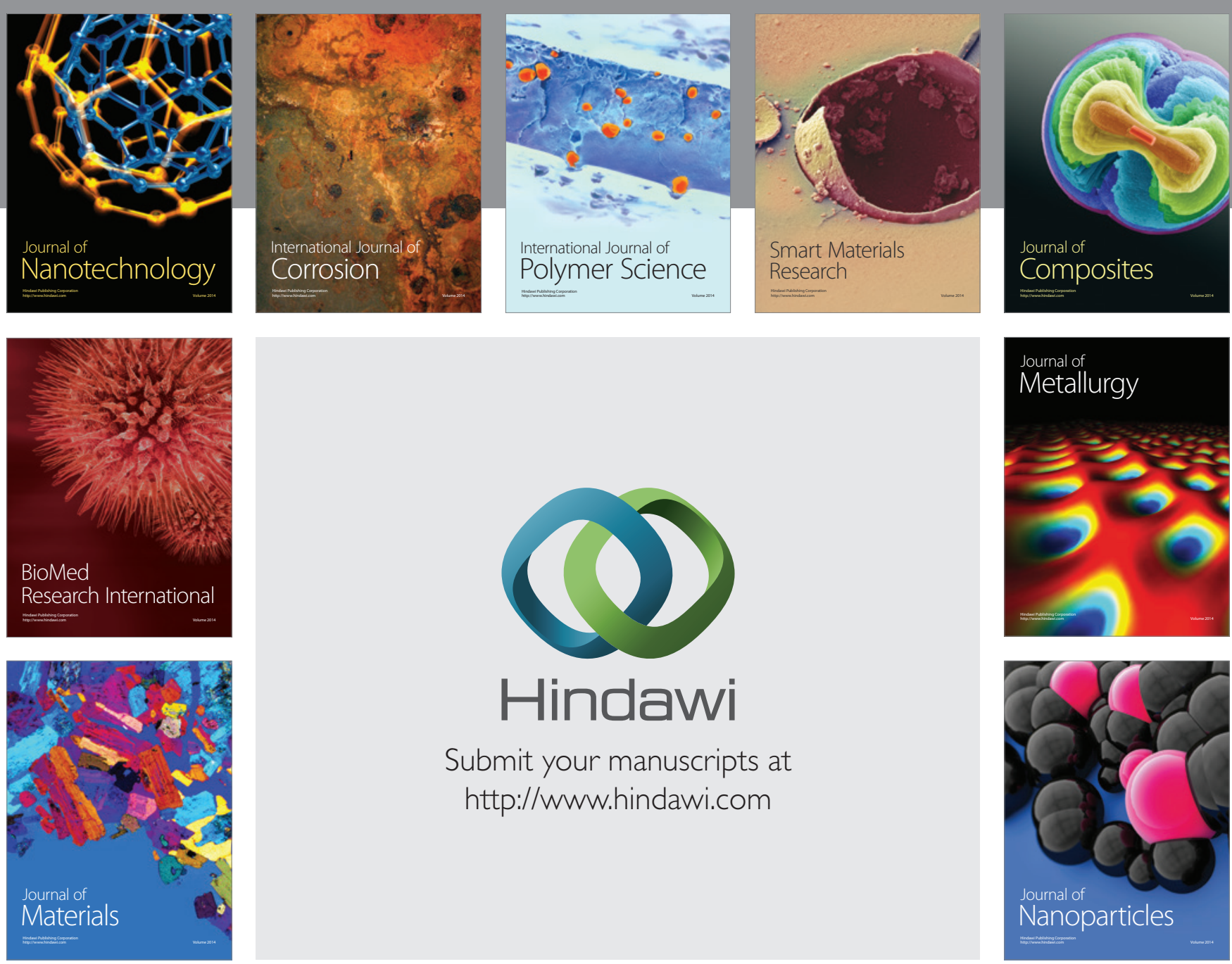

Submit your manuscripts at http://www.hindawi.com
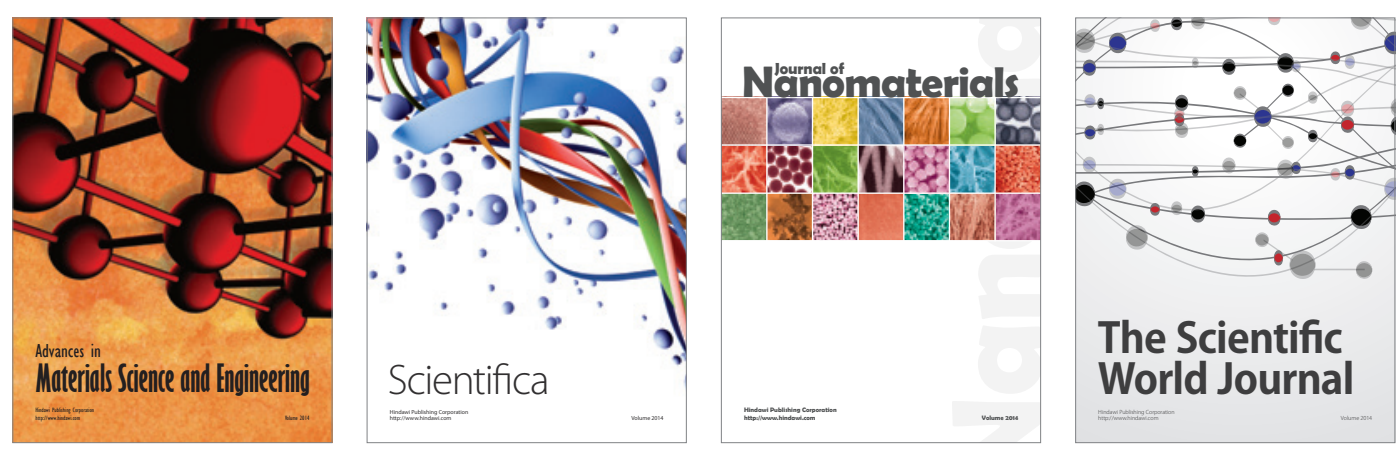

\section{The Scientific World Journal}
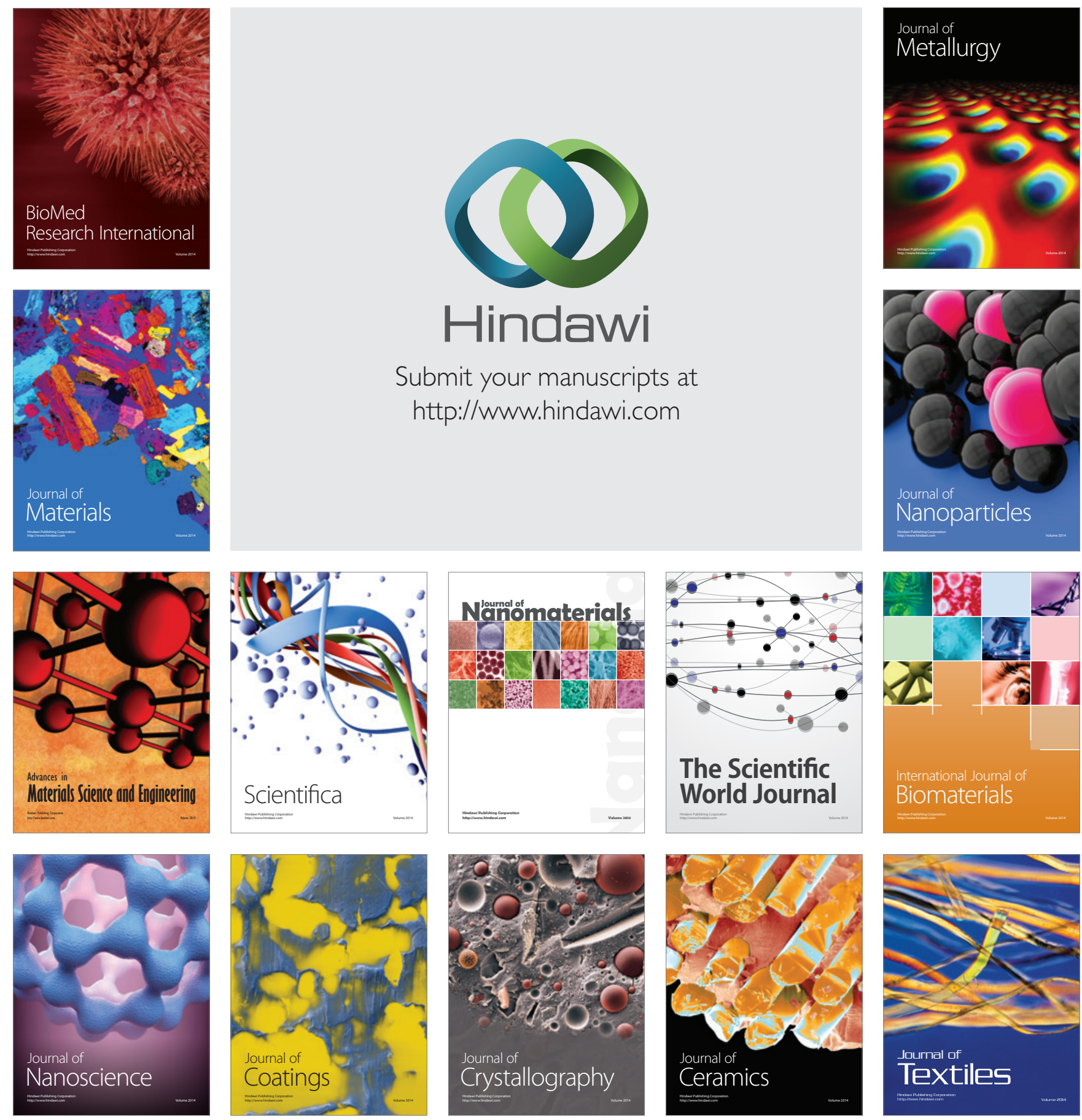